\title{
DIFFERENTIATION IN MORPHOLOGICAL CHARACTERISTICS AND MOTOR SKILLS OF YOUNGER SCHOOL-AGE STUDENTS
}

\author{
Dzevad Dzibric, Alen Kapidzic, Melika Muratovic, Tarik Ljubovic, Jasmin Bilalic, Sanjin Hodzic
}

Faculty of Physical Education and Sports, University of Tuzla

Original scientific paper

\begin{abstract}
Growth and development are indicators of good health, as well as a mirror of quality nutrition and quality of life. By monitoring growth and development, the relationship between motor abilities and morphological characteristics is recognized. The period of younger school age is characterized by strong growth and development of all anthropological dimensions, especially morphological and motor ones, which differ significantly in children, concerning adults. This transversal research aimed to determine the differences in morphological characteristics and motor abilities between lower primary school students. The research was conducted on a sample of 1233 girls, I - IV grades of primary schools from the area of the City of Tuzla. The sample of variables consisted of a set of 10 tests to assess certain anthropological dimensions (5 morphological and 5 motors), appropriate to the age of the study population. Univariate analysis of variance with multiple comparisons was used to determine the differences in the studied spaces between students of different grades, with the applied post hock Bonferroni test. The obtained results showed that there are statistically significant differences in all applied variables (morphological and motor). between treated groups at the level of significance $(p \leq 0.05)$. The results of the research draw attention to the importance of early stimulation of morphological-motor development and a healthy lifestyle in female students, which are characterized by regular physical activity and a healthy diet. Optimal levels of motor skills, well-developed fundamental motor skills and a healthy body structure are of great importance for health, quality of life-related to health and overall well-being of younger school-age students.
\end{abstract}

\section{INTRODUCTION}

Physical education is based on motor activity, which is used to accomplish certain tasks. Accordingly, students must be adequately engaged, and this primarily refers to the scope and intensity of their motor activity. In addition to developing motor skills, physical activity also affects the maintenance of healthy body weight (Halaši, 2016). One of the most important tasks in working with children is to take care of their growth and development. Especially in the period of younger school age, when the child goes to school. It is a sensitive period for him (Ćirović, N, 2018). The methodology of monitoring and evaluating the anthropological characteristics of students in the classroom represents procedures whose primary purpose is to gain insight into the current state of development of these characteristics with the aim of their development (Vidranski, 2020). The results of the diagnosis can also be used for: forecasting the development and transformation of anthropological characteristics, planning, programming and preparing the teaching process, recognizing and directing gifted children in a particular sport, monitoring body composition and fitness of students and directing students to appropriate kinesiological activities (Neljak et al ., 2011). Among other things, regular monitoring of body growth and development, starting with diagnostic evaluation, contributes to the detection of growth and development abnormalities, early identification of obesity and malnutrition (NCD Risk Factor Collaboration, 2019). It enables a more individual approach to students and better programming of physical education classes (Smajić et al., 2017). Nowadays, there is an increasing number of disturbing factors of proper physical maturation in children of younger school age (Lovrić, Mandić Jelaska, \& Bilić, 2018). In support of such a statement is the fact that this is one of the critical periods for the emergence of negative postural changes, which is certainly causally related to the parameters of growth and development. Morphological characteristics of young school children are very important for the realization of motor structures in which they represent a real biomechanical basis, both as factors that facilitate and as factors that make it difficult to perform motor tasks (Smajić et al., 2017; Arifi, Bjelica, \& Mašanović , 2019). Each motor ability is regulated by the appropriate mechanism of the central nervous system that controls it (Pejčić and Trajkovski, 2018). Motor abilities behave differently depending on biochemical and morphological changes in the organism. Each motor ability develops together with one or more of them, rarely independently (Kosinac, 2011). Recently, several studies have looked at the growth and development of young 
school children (Vasić et al., 2011; B. Krsmanović, Batez, \& T. Krsmanović, 2011; Vasiljević, Vukičević and Stoisavljević, 2015; Smajić et al., 2017).

Considering that this is the age of uniform development of psychosomatic status, and having in mind the results of previous research which indicate that in some cases there is a certain differentiation in terms of morphological and motor differences, the goal of this research is set. It refers to the determination of differences in morphological characteristics and motor abilities between students of I, II, III and IV grades of primary school.

\section{WORK METHODOLOGY}

\section{Sample of respondents}

The research was conducted on a sample of 1233 girls, I - IV grades of primary schools from the area of the City of Tuzla.

Only those subjects who are medically fit to attend physical and health education classes and who do not show any morphological, motor or psychological aberrations were subjected to the examination.

\section{Sample variables}

The sample of variables consisted of a set of 10 tests to assess certain anthropological dimensions, appropriate to the age of the study population (Hadžikadunić et al., 2000; Neljak et al., 2011). 5 variables were used to assess anthropometric characteristics: ATJVIS (body height), ATJMAS (body mass), BMI (body mass index), AONADL (upper arm circumference) and AKNNAD (upper arm fold). To assess motor skills, 5 variables were applied: MBFTAP (hand taping), MFESDM (long jump), MAPNTR (backward polygon), MRSTRB (sit-ups) and MFLPRE (forward incline).

\section{Data processing methods}

In the data analysis, the central and dispersive parameters arithmetic mean and standard deviation were calculated. Univariate analysis of variance with multiple comparisons was used to determine differences in morphological characteristics and motor abilities between lower primary school students, with the applied post hock Bonferroni test.

\section{RESULTS AND DISCUSSION}

Before analyzing variance, a procedure was performed to determine the homogeneity of variance to proceed with the further procedure. Leven's test confirmed disturbed homogeneity at the level $(p \leq 0.01)$ in morphological tests of body weight, circumference and skin fold of the upper arm, and in the motor test of the abdomen. Since a violation of the assumption of the equality of variance has been found, a stricter alpha level will be used to calculate the significance of the univariate F-test for these variables (Tabachnick \& Fidell. 2007). The stricter alpha level is $(p \leq 0.01)$

Analysis of variance revealed the existence of statistically significant differences in all applied variables (morphological and motor) between the treated groups at the level of significance $(p \leq 0.05)$.

Subsequent tests with the Bonferroni correction factor were used to determine between which classes there was a difference in the variables that showed the statistical significance of the differences. The results obtained in this study were compared with the results of similar studies and available standards for individual parameters. The World Health Organization believes that to adequately monitor the acceleration of growth and development, comparisons with defined national standards should be applied to eliminate the effects of numerous ethnographic differences (Banjević, 2019). When it comes to morphological variables, the obtained results show that younger school-age students differ statistically significantly in the variables body height and body weight. The height of female students ranges from ( $A S=125.35 ; S D=6.22)$ in the first grade to $(A S=142.34 ; S D=7.09)$ in the fourth grade, while body weight ranges from (AS =26). , 97; $S D=5.76$ ) in first grade to (AS = 37.53; SD = 9.34) in fourth grade. Differences in body height and body weight between these two-time points indicate that the increase in body height in female students, during the four years of class, is cumulatively about $17 \mathrm{~cm}$ in height and about $11 \mathrm{~kg}$ in weight. The annual increase in body height is about $6 \mathrm{~cm}$ and bodyweight about $4 \mathrm{~kg}$. The results are similar compared to previous research (Vasić, 2011; Jureša, Musil, \& Kujundžić Tiljak, 2012; Srpak, Tomac, \& Vidranski, 2015; Haywood \& Getchel, 2017; Ješić, 2017; Vidranski, 2020). What is characteristic of the period of leaving the phase of younger school age, girls in the prepubertal phase begin to gain weight (Mišigoj Duraković, 2008). If it is compared with the orientation values (Neljak et al., 2011), it can be concluded that these are average values. Analyzing the obtained values of the body mass index, it can be seen that only first-grade students differ statistically significantly from second-grade students, and it ranges from ( $A S=16.58$; $S D=$ $3.84)$ in the first grade to $(A S=18,37 ; S D=3.49)$ in the fourth grade. Body mass index is a rough indicator of obesity and obesity, ie. used as a good statistical measure of nutrition. It is 
calculated by dividing the body weight of a person in kilograms by the square of height in meters: A different categorization applies for those under 20 years of age, as children have different proportions and different height-toweight ratios than adults. Also, the degree of development differs between different ages and ethnic groups. Therefore, the determination of obesity in children is performed using appropriate percentiles for age and sex, obtained based on reference values and tables (Must, Dallal, \& Dietz, 1991). Below the 5th percentile indicates malnutrition, 5-15 percentile indicates an increased risk of malnutrition, 15-85 percentile indicates normal nutrition - adequate body weight, 85-95 percentile indicates an increased risk of overweight - the tendency to gain weight and over 95 percentile denotes overweight obesity (obesity). According to this criterion and the mean values of the examined sample, it can be concluded that the students have an adequate body weight (15-85 percentile). The limitation of this index is the impossibility of distinguishing muscle from adipose tissue in the total mass of a developing individual (Mišigoj Duraković, 2008).
The obtained results are compatible with previous research (Abazović et al., 2016; Čolakhodžić et al., 2017). The obtained information on the growth of children in height and their body weight very often serves as indicators of children's health status and nutrition, as well as evaluation of their growth and development rate (Medved et al., 1987; Pavlović, 1999; Božić-Krstić et al., 2003). In the variable upper arm circumference, first-grade students differ statistically significantly from second-grade students, as well as the existence of statistically significant differences between second and third-grade students. Statistically significant differences between the examined groups of girls also exist in the variable skin fold of the upper arm (first and third, first and fourth and second and fourth grade). These results may be due to different diets and levels of physical activity of first graders. These children from a world of play and leisure that adorned their previous childhood, enter a world characterized by a sedentary lifestyle, with a multitude of commitments and commitments, and school obligations (Malina \& Bouchard, 1991).

Table 1. Arithmetic mean \pm standard deviation (minimum and maximum value); ANOVA (F - test, statistical significance), morphological characteristics and motor abilities of students of different grades

\begin{tabular}{|c|c|c|c|c|c|c|}
\hline \multirow[t]{2}{*}{ VARIABLES } & \multirow{2}{*}{$\begin{array}{l}\text { GRADE } 1 \\
(N=302) \\
A S \pm S D\end{array}$} & \multirow{2}{*}{$\begin{array}{c}\text { GRADE } 2 \\
(N=308) \\
A S \pm S D\end{array}$} & \multirow{2}{*}{$\begin{array}{c}\text { GRADE } 3 \\
(N=309) \\
A S \pm S D\end{array}$} & \multirow{2}{*}{$\begin{array}{c}\text { GRADE } 4 \\
(N=314) \\
A S \pm S D\end{array}$} & \multicolumn{2}{|c|}{ ANOVA } \\
\hline & & & & & $\mathrm{F}$ & Sig. \\
\hline ATJVIS & $\begin{array}{c}125.35 \pm 6.22 \\
(101.50- \\
148.00)\end{array}$ & $\begin{array}{l}131.65 \pm 6.76 * \\
(113.60-165.00)\end{array}$ & $\begin{array}{c}137.23 \pm 6.23 * \dagger \\
(115.70-161.50)\end{array}$ & $\begin{array}{c}142.34 \pm 7.09 * \\
t \neq \\
(126.00-173.40)\end{array}$ & 4.84 & 00 \\
\hline ATJMAS & $\begin{array}{l}26.97 \pm 5.76 \\
(17.90-47.10)\end{array}$ & $\begin{array}{r}30.94 \pm 7.93 * \\
(19.20-66.10)\end{array}$ & $\begin{array}{c}34.59 \pm 7.98 * \dagger \\
(14.80-59.80)\end{array}$ & $\begin{array}{c}37.53 \pm 9.34 * \\
t \neq \\
(23.00-88.80)\end{array}$ & 5.49 & 00 \\
\hline BMI & $\begin{array}{l}16.58 \pm 3.84 \\
(12.86-24.96)\end{array}$ & $\begin{array}{l}17.69 \pm 3.41 \text { * } \\
(10.32-34.86)\end{array}$ & $\begin{array}{c}18.25 \pm 3.39 \text { * } \\
(8.62-30.04)\end{array}$ & $\begin{array}{r}18.37 \pm 3.49 * \\
(11.79-31.31)\end{array}$ & 5.27 & 00 \\
\hline AONADL & $\begin{array}{c}19.76 \pm 2.72 \\
(7.00-28.00)\end{array}$ & $\begin{array}{r}20.78 \pm 3.29 * \\
(12.50-34.00)\end{array}$ & $\begin{array}{c}21.74 \pm 3.19 * \dagger \\
(9.00-32.00)\end{array}$ & $\begin{array}{r}22.35 \pm 3.17 \text { * } \\
(16.00-32.50)\end{array}$ & 5.51 & 00 \\
\hline AKNNAD & $\begin{array}{l}13.81 \pm 2.07 \\
(5.40-36.00)\end{array}$ & $\begin{array}{l}14.75 \pm 2.92 \\
(4.00-40.00)\end{array}$ & $\begin{array}{c}15.73 \pm 2.88 \text { * } \\
(3.00-36.00)\end{array}$ & $\begin{array}{c}15.99 \pm 2.53 * \\
t \\
(6.00-36.00)\end{array}$ & 4.70 & 00 \\
\hline MBFTAP & $\begin{array}{l}17.26 \pm 3.60 \\
(9.00-42.00)\end{array}$ & $\begin{array}{l}19.29 \pm 2.84 * \\
(7.00-77.00)\end{array}$ & $\begin{array}{l}21.22 \pm 3.84 * \\
(7.00-46.00)\end{array}$ & $\begin{array}{c}22.35 \pm 3.69 * \\
\dagger \\
(11.00-60.00) \\
\end{array}$ & 2.32 & 00 \\
\hline MFESDM & $\begin{array}{c}97.12 \pm 19.76 \\
(30.00- \\
150.00) \\
\end{array}$ & $\begin{array}{c}101.37 \pm 18.12 \text { * } \\
(50.00-160.00)\end{array}$ & $\begin{array}{c}110.39 \pm 20.41 \text { * } \\
\dagger \\
(59.00-190.00) \\
\end{array}$ & $\begin{array}{c}115.04 \pm \\
20.87 *+\neq \\
(50.00-170.00) \\
\end{array}$ & 3.60 & 00 \\
\hline MAPNTR & $\begin{array}{l}25.12 \pm 3.14 \\
(9.06-75.20)\end{array}$ & $\begin{array}{l}23.60 \pm 3.02 \\
(8.00-61.77)\end{array}$ & $\begin{array}{l}22.13 \pm 2.44 * \\
(10.03-64.00)\end{array}$ & $\begin{array}{c}20.99 \pm 2.97 * \\
\dagger \\
(9.00-96.13) \\
\end{array}$ & 1.89 & 00 \\
\hline MRSTRB & $\begin{array}{l}12.39 \pm 7.37 \\
(0.00-37.00)\end{array}$ & $\begin{array}{l}15.25 \pm 8.03^{*} \\
(0.00-43.00)\end{array}$ & $\begin{array}{c}18.58 \pm 9.23 * \dagger \\
(0.00-42.00)\end{array}$ & $\begin{array}{c}21.28 \pm \\
11.88 * t \neq \\
(0.00-86.00)\end{array}$ & 7.94 & 00 \\
\hline MFLPRE & $\begin{array}{l}45.59 \pm 9.78 \\
(13.00-83.00)\end{array}$ & $\begin{array}{l}48.55 \pm 10.52 \\
(15.00-97.00)\end{array}$ & $\begin{array}{c}49.16 \pm 9.70 \text { * } \\
(0.00-101.00)\end{array}$ & $\begin{array}{c}52.45 \pm 9.78 * \\
+\neq \\
(16.00-102.00)\end{array}$ & 5.85 & 00 \\
\hline
\end{tabular}

* STATISTICALLY IMPORTANT DIFFERENCES COMPARED TO VALUE OF 1st GRADE; P $\leq .05$.

+ STATISTICALLY IMPORTANT DIFFERENCES COMPARED TO VALUE OF 2nd GRADE; $P \leq .05$

\# STATISTICALLY IMPORTANT DIFFERENCES COMPARED TO VALUE OF 3rd GRADE; $P \leq .05$. 
When it comes to motor variables, the obtained results show that younger school-age students differ statistically significantly in all applied variables. In the variable taping by hand, statistically, significant differences were mostly achieved by first-grade students with other grades. It is a variable for estimating the frequency of movement, and in itself saturates one extremely important motor ability in certain sports activities, and that is the speed of simple movement, which is more developed in older age. In the variable long jump from the place, statistically, significant differences were achieved between all examined groups of female students. Mean values are higher in older students, and the increase in muscle mass until puberty is due to the action of growth hormone-like insulin (Israel, 1991). Slightly weaker results were achieved concerning research (Klek, Trajkovski \& Ljubičić, 2020). With the variable polygon backwards, there are statistically significant differences between first and third and fourth-grade students and second and fourth-grade students, respectively. This is to be expected, because the motor development of children of younger school age is influenced by the process of myelination, which in turn affects the development of coordination (Neljak, 2013), and this motor ability is only differentiated in prepuberty (Mišigoj-Duraković, 2018). In the abdominal variable, statistically significant differences were achieved between all examined groups of female students. Given that there are differences in the values of body mass index growth, and thus body composition between female students, it is to be expected that these differences cause relationships in relative repetitive strength between female students (Vidranski, Tomac, \& Otković, 2017). When it comes to the variable for assessing flexibility inclination, we see that statistically significant differences have fourth-grade students with students of other grades. These results also confirm the results of previous research conducted by Gabbard \& Tandy, 1988; Raspberry, Bouchard \& Bar-Or, 2004).

\section{CONCLUSION}

The obtained results show that statistically significant differences were found between the tested subsamples. Analysis of variance revealed the existence of statistically significant differences in all applied variables (morphological and motor) between the treated groups at the level of significance $(p \leq 0.05)$. Differences between subsamples (grades) were most pronounced between first-graders and secondgraders. Statistically significant differences between all examined groups appeared in the variables body height, body weight, hand taping, long jump and sit-ups.

The consequences of poorly developed morphological characteristics that accompany obesity are numerous, from the impaired motor and cognitive abilities to growth disorders in children, as well as consequences that negatively affect social and emotional development. The previously mentioned problems have an equally negative impact on the development of female students, by which it is necessary to take the necessary steps in the prevention of this dangerous phenomenon in modern times. The results of the work provide primary school teachers and kinesiologists with an insight into the level of growth and development of younger school-age students, as well as the current differences between these anthropological dimensions according to age criteria. Timely measurement and monitoring of anthropological dimensions enable their orientation towards sports disciplines, and not only individual anthropological parameters, but also their mutual relations have a crucial role. For these reasons, recently, a large number of students are involved in various sports activities and programs, and the opportunities provided by the environment from which they come are extremely good.

\section{LITERATURE}

1. Abazović, E., Hasanbegović, S., Kovačević, E., Okanović, I., Kazazović, E., Ademaj, Z., Lakota, R. and Mekić, A. (2016). Obesity of primary schoo/ children in Sarajevo Canton. Sarajevo: Ministry of Education, Science and Youth of Sarajevo Canton, Ministry of Health of Sarajevo Canton.

2. Arifi, F., Bjelica, D., Mašanović, B. (2019). Differences in anthropometric characteristics among junior soccer and handball players. Sport Mont, 17(1), 45-49.

3. Banjević, B. (2019). Differences in Some Morphological Characteristics and Body Mass Index in Children of Younger School Age concerning Their Gender. J. Anthr. Sports Phys. Educ. 3(3), 37-41.

4. Božić-Krstić, V., Rakić, R. and Pavlica, T. (2003). Body height and weight of preschool and younger schoolchildren in Novi Sad. Glasnik Antropološkog društva Jugoslavije, 38, 91-100.

5. Gabbard, C. \& Tandy, R. (1988). Body composition and flexibility among prepubescent males and females, J Human Move Stud 14(4), 153-159. 
6. Krsmanović, B., Batez, M. and Krsmanović, T. (2011). Differences in anthropometric characteristics and nutrition in boys and girls. Glasnik Antropološkog drustva Srbije, 46, 89-94.

7. Čolakhodžić, E., Vuk, N., Habul, Ć., Vujica, S. and Tanović, S. (2017). Obesity and postular status of primary school children in the City of Mostar. Mostar: Faculty of Teacher Education, University "Džemal Bijedić"

8. Ćirović, N. (2018). Comparative analysis of motor and morphological status of children in the first cycle of primary school, northern, middle and southern regions of Montenegro. Master's thesis, Nikšić: Faculty of Sports and Physical Education.

9. Hadžikadunić, M., Rađo, I., Grozdanić, B. and Turković, S. (2000). Eurofit battery test guide. Sarajevo: Madž.

10. Halaši, S. (2016). Body structure and motor status as predictors of quality of life of younger school-age children. Doctoral dissertation, Novi Sad: Faculty of Sports and Physical Education.

11. Israel, S. (1991). Age-related change in strength and special group. Strength and Power in Sport (pp. 319328) Blackwell, Boston.

12. Klek, J., Trajkovski, B. and Ljubičić, S. (2020). Differences in explosive strength of the lower extremities in children of early school age. ERS - Education, Recreation, Sports, 42, 32-36.

13. Kosinac, Z. (2011). Morphological-motor and functional development of children aged 5 to 11 years. Split: Association of School Sports Associations of the City of Split.

14. Lovrić, F., Mandić Jelaska, P., \& Bilić, Z. (2018). Physical activity cannot be treated as a predictor of anthropological status among six-year-old children. Montenegrin Journal of Sports Science and Medicine, 7(1), 53-57.

15. Malina, RM \& Bouchard, C. (1991). Growth, Maturation, and Physical Activity. Seatle: Human Kinetics Books.

16. Malina, R., Bouchard, C. \& Bar-Or, O. (2004). Growth, maturation and physical activity, Champaign, USA: Human Kinetics.

17. Medved, R., Barbir, Ž., Brdarić, R .., Gjurić, Z., Heimer, S., Kesić, B., Medved, V., Mihelić, Z., Pavišić-Medved, V., Pećina, M., Todorović, B., Tucak, A. and Vuković, M. (1987). Sports medicine. Zagreb: Jumena.

18. Mišigoj-Duraković, M. (2008). Kinanthropology: biological aspects of physical exercise, Zagreb: Faculty of Kinesiology

19. Mišigoj-Duraković, M. (2018). Physical exercise and health, Zagreb: Znanje.

20. Must, A., Dallal, GE., \& Dietz VH. (1991). Reference data for obesity: 85th and 95th percentiles of body mass index (wt / $\mathrm{ht}^{2}$ ) and triceps skinfold thickness. Am J Clin Nutr, 53: 839-846.

21. NCD Risk Factor Collaboration (2019). The rising rural body-mass index is the main driver of the global obesity epidemic in adults. Nature, 569, 260-264.

22. Neljak, B. (2013). Kinesiological methodology in primary and secondary education, Zagreb: Gopal doo

23. Neljak, B., Novak, D., Sporiš, G., Visković, S. and Markuš, D. (2011). Methodology for evaluating the anthropological characteristics of students in physical and health culture CRO-FIT STANDARDS, Zagreb: Faculty of Kinesiology, University of Zagreb.

24. Pavlović, M. (1999). Nutrition of children in the Severnobac district. Subotica: Institute for Health Protection.

25. Pejčić, A., Trajkovski, B. (2018). What and how to practice with children in kindergarten and school. Rijeka: Faculty of Teacher Education.

26. Smajić, M., Marinković, A., Đorđić, V., Čokorilo, N., Gušić, M. \& Štajer, V. (2017). Differences in morphological characteristics and motor abilities of girls and boys of younger school age. Glasnik Antropološkog drustva Srbije, 52, 89-93.

27. Tabachnick, BG, \& Fidell, LS (2007). Using Multivariate Statistics (5th ed.). New York: Allyn and Bacon.

28. Vasić, Z., Vidović, S., Šuščević D., Karan, Ž., Lončar, M., Ramić, I. \& Dragić S. (2011). Anthropometric analysis of primary school students in a rural area. Glasnik Antropološkog drustva Srbije, 46, 95-102.

29. Vasiljevic, D., Vukicevic, T., and Stoisavljevic, M. (2015). Nutritional status of younger school-age students. Proceedings of the Faculty of Teacher Education, 9, 237-245.

30. Vidranski, T., Tomac, Z., \& Otković, P. (2017). The application of the raising of the torso from a lying position test (MRSPTL) in 30 and 60 seconds in elementary school pupils [Paper presentation]. In Proceedings book: Contemporary kinesiology. 5th International Scientific Conference "Contemporary Kinesiology", (Croatia), Split, (pp. 281 - 288).

31. Vidranski, T. (2020). Reliability and orientation values of CROFIT tests in classroom teaching. Progress 161 (34) $185-202$.

\section{Corresponding author:}

Dževad Džibrić, PhD.

Faculty of physical education and sport, Tuzla University

e-mail: dzevad.dzibric@untz.ba 